\title{
THE INTERNATIONAL COPYRIGHT UNION
}

\author{
THORVALD SOLBERG
}

In the article "Copyright Law Reform" printed in the YALE LAW JOURNAL for November 1925 the early proposals for securing copyright protection in the United States for the works of foreign authors by means of an international copyright treaty were briefly considered. References were made to Lord Palmerston's proposed treaty of 1839 ; the convention between Great Britain and the United States actually concluded in 1853, but not ratified; and Lord Clarendon's draft of 1870. The next movement towards securing international copyright by way of a treaty was suggested by Messrs. Harper \& Brothers to the Hon. William M. Evarts, Secretary of State, in a letter dated November 25, 1878, transmitting a draft for a copyright convention between the United States and Great Britain. In 1879 these publishers printed a sixteen page quarto pamphlet entitled "Memorandums in regard to an International Copyright Treaty between Great Britain and the United States," which contained, in addition to the letter addressed to the Secretary of State, the text of Lord Clarendon's treaty (1870) and, in parallel columns under the heading "Proposed amendments," what was virtually a substitute draft for such a treaty.

In addition the volume contained the text for "An Act to secure Copyright to Foreign Authors and Artists," proposed by Mr. William H. Appleton, the well-known publisher; extracts from a letter by Mr. Appleton to the London Times in defense of his position; and an extract from the "Address on International Copyright," delivered by Mr. George Haven Putnam in New York on January 29, 1879.

The treaty draft is anonymous but its authorship was ascribed to the publishers, Harpers and Appletons, and it was commonly designated the "Publishers' Copyright Convention." It was drawn up and printed in the form of a completed treaty ready for signature; but Mr. Edward Thornton, the British Minister at Washington, in his dispatch of November 23, 1880, quotes Secretary Evarts as explaining that it was "merely a sketch drawn up by certain individuals who were interested in the matter" upon which he had wished to elicit the opinion of Her Majesty's Government, but that he "could not at all engage that his Government would abide by the proposals comprised in that document."

The fundamental provision of this proposed treaty may be briefly summarized as follows: English authors were to be ac- 
corded copyright protection in the United States and American authors in Great Britain; the protection in each case to be in accordance with the laws in force or subsequently enacted in each country for the copyright protection of its nationals, and to include the right of representation of dramatic works and of performance of musical compositions "in so far as the laws of each of the two countries are or shall be applicable in this respect to dramatic and musical works first publicly represented or performed therein." Piratical copies were prohibited importation, and infringers of the copyright might be prosecuted according to the law of the country in which the infringement took place.

The conditions prescribed for obtaining copyright were: (a) compliance with the laws and regulations of the respective countries in regard to copyright; (b) that a work manufactured and published in one country to secure copyright in the other country must also have been "manufactured and published therein by a subject or citizen there of within three months after its original publication in the country of the author"; (c) a registration of the title of the work "in the author's name" must have been made in both countries before first publiention or sale of the work in the author's country; and (d) the deposit as specifically indicated of one copy of the work must have taken place within three months after first publication in the country of origin. The requirement of manufacture was not to be held to prohibit "printing in one country from-stereotype plates prepared in the other and imported for that purpose." The convention was to continue for five years with yearly prolongation if not denounced.

Mr. Appleton's bill which was first presented to the committee on the Library of the House of Representatives in 1872 was very brief, providing that any author or artist, not a citizen of the United States, might secure copyright for his work provided it was monufactured and published in the United States. In the case of a translation, in addition to such manufacture, the deposit of a copy for registration in the Library of Congress within one month after publication abroad was required, as was an announcement on the title page of the original work that it was the intention of the author to translate it.

It was a publishers' bill with the protectionist element accentuated. If the foreign author manufacturcd his worl in the United States he might secure copyright protection in the United States.

It is interesting to compare this proposal with the text of a bill drafted about the same time, erroneously ascribed to Mir. Charles Astor Bristed, but actually prepared by the executive committee of the American Copyright Association comprising 
Dr. Prime, George Palmer Putman, S. S. Cox, Henry Holt, Charles Scribner, Edmund C. Stedman and Richard Grant White, secretary. The president of the Association was William Cullen Bryant, and among the vice-presidents were Longfellow, George William Curtis and Horace Greeley.

This bill was submitted to the chairman of the joint committee on the Library by Mr. White on February 12, 1872. A House resolution had been passed on December 18, 1871, directing the joint committee on the Library

\begin{abstract}
"to consider the question of an international copyright and to report to the House what, in their judgment, would be the wisest plan, by treaty or law, to secure the property of authors in their works, without injury to other rights and interests; and if, in their opinion, congressional legislation is the best, that they report a bill for that purpose."
\end{abstract}

A public hearing was announced, beginning on February 12, 1872, and invitations were sent out to authors, publicists and publishers to appear before the committee and present their views of the question. At this hearing, Mr. Bristed reported, Mr. Appleton offered to withdraw his bill and accept the Copyright-Association bill if it were amended by adding the requirement that the book to be protected should be manufactured in the United States. Following the hearings, Senator Morrill submitted on February 7, 1873, an adverse report which concluded as follows:

"In view of the whole case, your committee are satisfied that no form of international copyright can fairly be urged upon Congress upon reasons of general equity, or of constitutional law; that the adoption of any plan for the purpose which has been laid before us would be of very doubtful advantage to American authors as a class, and would be not only an unquestionable and permanent injury to the manufacturing interests concerned in producing books, but a hindrance to the diffusion of knowledge among the people, and to the cause of universal education.

The text of the bill by the Copyright Association read as follows-it needs no comment:

"Sec. 1. All rights of property secured to citizens of the United States of America by existing copyright laws of the United States are hereby secured to the citizens and subjects of every country the government of which secures reciprocal rights to citizens of the United States.

Sec. 2. This Act shall take effect two years from the date of its passage."

In their letter addressed to the Secretary of State Messrs. Harper \& Brothers say : 
"It does not seem to us that any action originating exclusively either in our country or in any foreign country would ever be likely to result in the establishment of International Copyright: The various bills to accomplish this object which have been proposed from time to time in Congress have conspicuously, and, we think, deservedly failed. . . . As the last proposition for an international copyright treaty came from England, it would seem proper that the next proposition looling to such a measure should emanate from the United States, and to that end we make the following suggestion:

"That a commission or conference of eighteen American citizens and British subjects, in which the United States and Great Britain shall be equally represented, be appointed re. spectively by our Secretary of State and by the British Secretary of State for Foreign Affairs, who shall be invited jointly to consider and present the details of a treaty to be proposed by the United States to Great Britain. We further suggest that in each country the commission should be composed of three authors, three publishers, and three publicists."

The Harper document was reprinted in 1380, extended to fiftyfive pages by the inclusion of articles from the pens of $S$. $S$. Connant, Leonard H. Courtney and Matthew Arnold called out by the former widely distributed pamphlet.

President Arthur's first annual message, dated December 6, 1881, contained this laconic sentence-"Negotiations for an international copyright convention are in hopeful progress." No explanation is vouchsafed concerning this, but the "negotiations" referred to, which antedated the movement for an International Copyright Union, no doubt comprised the correspondence between the United States and Great Biitain, begun in 1879 , after the presentation and publication of the HarperAppleton draft for a copyright treaty.

Very considerable interest in the subject of international copyright or protection in the United States for the works of foreign authors was aroused by the wide distribution and extensive consideration of the Harper proposal resulting not only in the appearance of many articles on copyright in American and English magazines and newspapers but also in the presentation of a memorial from American authors in favor of international copyright. Included among the signatures vere those of Henry W. Longfellow, Oliver Wendell Holmes, Ralph Waldo Emerson, John Greenleaf Whittier, William Dean Howells, Thomas Bailey Aldrich, Charles Dudley Warner, George William Curtis, Harriet Beecher Stowe, Louiss MI. Alcott, Philip Schaff, Henry W. Bellows and Prof. Asa Gray.

A petition was also presented to both Houses of Congress in December 1880 and again in January 1881 signed by Theodore D. Woolsey and seventy-two others, including Edward Everett Hale, John G. Holland, Mary Mapes Dodge, Du. Austin Flint, 
Dr. Austin Flint, Jr., C. L. Brace, Dr. J. C. Dalton, five firms in St. Louis, including Robert Patterson \& Company and the Hildreth Printing Company, and a number of residents of Philadelphia, including T. S. Arthur, Dr. Alfred Stillé, H. C. Lea's Sons \& Co., Porter \& Coates, Henry C. Baird \& Co., J. M. Stoddart \& Co., T. B. Peterson \& Co. and MacKellar, Smiths' \& Jordan. This petition was in favor of the enactment of an international copyright law but with objections expressed "against legislation upon the subject under the guise of a treaty."

The latter petition was accompanied by the draft of a law which the petitioners desired should be passed. The first section of this proposed measure made it lawful for any citizen of the United States to hold and enjoy by assignment from the author the copyright in any work by a citizen or subject of a foreign country as fully as if the assignor were a citizen of the United States, provided the work should have been wholly manufactured, published and offered for sale in the United States within two months after the date of its first publication in the country of origin. In the case of translations the time limit was extended to four months, and to six months in case of a dramatic composition, between first representation abroad and representation in the United States. Reciprocity was to be required and proclaimed by the President and the protection only applied to publications issued after the passage of the bill. Registration of title was required and the printing of a catalogue of copyright entries. Assignment to any one not a resident of the United States was ground for the forfeiture of the copyright; and republication thereafter by anyone was permitted.

The space allotted for this article precludes any attempt to give a complete record of the harvest of newspaper and periodical articles relating to international copyright which resulted from this particular agitation. Any one curious enough can learn something of its extent by referring to my "Bibliography of Literary Property," pages 35 to 37, where three quarto double-column pages of fine print are required to list briefly the titles of the contributions to The Publishers' Weelly alone from 1879 to 1882 . The printed discussion continued during the following two years, 1883 and 1884, though the literature was not proportionally voluminous. But it may be worth while to refer here to a few of the outstanding articles which indicated the feeling prevalent at the time in relation to protection in the United States for alien authors. It will be found that among authors the prevailing opinion was in favor of justice being rendered to the foreign writer: The publisher's also felt the need for some action to cure the evil of the existing widespread literary piracy, which had grown beyond control; but 
demanded the protection of their interests by insistence upon the remanufacture of the foreign author's book in the United States. Their trade organ, The Publishcrs' Wcelly, while pronounced in its favor of international copyright, supported the publishers' contention.

Among the outstanding press notices was a letter which appeared in the New York Herald for October 4, 1880, under the title "International Copyright," lnown to be from the pen of Eaton Sylvester Drone, the author of the well-kmown rork on Copyright Law. Mr. Drone, in support of protection in the United States for foreign authors, wrote:

"Intellectual productions have all the attributes of property, and by every principle of law and reason, by every consideration of right and justice, the title to this property is not less perfect and should be not less inviolable than the title to any other species of property. . . . The right principle of international protection to literary property is that advocated in England. The English proposition is that British copyright be recognized in the United States, and American copyright in Great Britain, so that a book published in either country shall be fully protected in the other without the necessity of republication. This is international copyright. . . . England not only stands ready to enter into a treaty to secure this end, but is willing to go further and extend British copyright to American authors who first publish in Great Britain. This is a wise and statesmanlike course which our Government should not hesitate to adopt. Let American copyright be given by Act of Congress to every foreign author who publishes first in this country, and let the copyright of works published abroad be protected here by treaty.

MIr. Drone concludes with an expression of approval of Harper \& Brother's' suggestion for an international conference of authors, publishers and publicists.

The opposition to international copyright was centered at Philadelphia, Mr. Henry Carey Baird, the leading outspolien opponent, declaring himself "opposed to all international copyright no matter how much soever it might be sugar-coated so as to make it palatable to the American publisher." The Bools Trade Association of that city published a resolution in the National Republican of October 26, 1880, declaring that they were "wholly opposed to the settlement of the international copyright question by the medium of a treaty," and regarded this treaty as highly objectionable.

Following this action an editorial under the title "International Copyright Again" appeared in the New York Tribune for November 27, 1880, beginning as follows:

"Eight years ago a conference on international copyright was held at Philadelphia, and resolutions were adopted to the effect that, 'thought, when given to the world, is, as light, free to all,' and that the safety of republican institutions would be en- 
dangered if 'foreign authors' had the power to fix the price of their books in this country."

The writer admits, however, that the persons concerned had "advanced a good way beyond the bunkum resolution of 1872" ; and that they had come to recognize the justice-or at least the convenience- of protecting foreign authors. In a final paragraph he continues:

"The great obstacle to the conclusion of an international copyright agreement has hitherto been that the foreign publisher insisted upon our granting him the privilege of controlling the American market and forcing us to buy expensive books of him, instead of reprinting them in the cheap editions which our readers require; in other words, we have been asked to protect the foreign publisher instead of the foreign author. The trouble now seems to be that American publishers, in their schemes for an arrangement with Great Britain, are committing the same fault for which they blame their English brethren. They are proposing laws and treaties entirely for the protection of the American firms engaged in reprinting foreign books."

The Boston Herald, entered into the controversy with an article on "International Copyright," with special reference to Mr. Henry Carey Baird's adverse arguments, which article was reprinted in the New York Evening Post of November 27, 1880. The writer points out that there were nine English authors read in this country to one American, and that the reason for it lay in the fact that the works of English authors may be reprinted without payment of any royalty to the foreign author.

He wrote as follows:

"The author's percentage in an American book is a direct burden upon its sale, and, consequently, without the work has extraordinary merit, or can be obtained without payment, the publisher is no more than prudent in declining to have anything to do with it. The consequence of this is evident enough; the Americans, as Mr. Baird justly says, are the greatest reading people in the world, but they are virtually a people without authors.

"Surely Mr. Baird does not need to be told that, if this labor" of the brain was protected by forcing our publishers to pay for English copyrights, it would thrive under the encouragement. - - His plea that, under an international copyright, the English will take possession of our book market, is a thoroughly unsound one. They have possession now and have crowded the poor American author over to the wall; for the fact that they are paid nothing for their goods does not change the condition of possession. . . . If they [the American publishers] were compelled to pay English authors, the number of English works that would be republished here would be greatly reduced. Instead of the English then having possession of the market, it would afford the American author a chance to contest possession with them on something approaching an even footing." 
While many of the published contributions dealt with the subject of international copyright generally rather than with the actual text of the Harper-Appleton proposed treaty, the publisher's' own organ, The Publishers' IFeclily, was emphatic in its advocacy of the treaty draft, holding that "the so-called opposition in this country to international copyright was rather and chiefly opposition to such a form of international publishing-right as would give to English publishers an advantage, decided and absolute, over American publisher's in the American market." In a notice of the pamphlet entitled "Copyright, National and International" by the well-known English publisher Mr. MIarston, it pronounced his "pleading for a simple copyright without any haggling over manufacturing conditions" as the "delightfully ingenuous view so long put forward by most English publishers," and contended that in that case "the English publisher would try to bag the American marliet without giving the American publisher a chance to treat with the author at all."

This journal distributed a series of questions to well-linown authors and leading publishers ashing if they favored international copyright and how it was to be accomplished. A large number of authors and publishers responded, for the most part in the affirmative. A few authors approved the requirement of American manufacture, while the publishers nearly all were insistent upon its absolute necessity, a noticeable exception being Roberts Brothers of Boston. Occasionally some authors replied with a refreshing frankness and emphasis. Dr. Edward Eggleston, who later on performed a notable service in the aid he rendered in securing the Copyright Act of 1891 which extended protection to foreign authors, wrote as follows:

"I do not think a simple question should be befogged. There is but one practical plan as there is but one just plan-to accord to an author entire control of the product of his brain. . . . The publisher has no legitimate interest beforehand in any author's work. Let all questions between publisher and author and public be settled as other trade questions are. . . ."

Two noticeable contributions to the controversy were "The American View of the Copyright Question" by Richard Grant White, and "The Right of Copyright" by S. Irenaeus Prime, editor of the New York Observer. MIr. White says of the proposed treaty, "First, it is unjust to the British author, and to all authors; second, it would be null and void, and would afford no protection either to the British author or his American publisher."

Dr. Prime controverts the arguments of Mr. Henry Carey Baird, and sums up the matter as follows: "An International Copyright Law is, therefore, simple justice between man and 
man. The author's moral right being perfect, as the right of any other person to his property, Government is bound to make the legal right commensurate therewith."

Three American members of the International Copyright Committee of the British Association for the Reform and Codification of the Laws of Nations, John Jay, James Grant Wilson and Nathan Appleton, wrote Secretary Evarts under date of February 11, 1880, with reference to the proposed treaty, advancing the following suggestions:

"We are inclined to believe . . . that an international copyright has become desirable, not only as a matter of justice to American authors, but on the ground of practical expediency, and indeed necessity, to give new life and strength to the American book trade, and to supply the basis of certainty which is essential to confidence and successful competiton: . . . The plan proposed would give to the American author the same rights in Great Britain which belong to the English author, and to the English author the same rights in the United States that belong to the American author; with the proviso that the work, within a reasonable time after its first publication in the country of the author, be manufactured and published in the other by a citizen or subject thereof. . . That this scheme will have advantage for our authors and all concerned in the manufacture of books, is frankly admitted by the leading publishers; and the reading public of America as of England, should be benefited by the new encouragement to literature, science, and art in both countries that is expected to result from an international copyright."

The draft of the International Copyright Convention submitted by Harper \& Brothers was communicated by Mr. James Russell Lowell, the American Minister in London, to Lord Granville, and transmitted by him to the British Board of Trade for its consideration in September 1880.

Mr. Edward Thornton, British Minister at Washington, in his dispatch of November 23, 1880, wrote that he had imagined that the draft had been officially submitted as the settled proposal of the United States government but that Mr. Evarts had stated that if Mr. Lowell had done so he had mistaken the instructions which had been forwarded to him, and the Secretary had added that

"there were so many conflicting interests depending upon the question that, whatever might be the terms of convention which might be concluded, it would be impossible to say or even divine beforehand whether it would receive the sanction of the Senate or not."

Thereupon a request was made by the British Board of Trade to Mr. Lowell for authority to submit the draft convention transmitted by him to English authors and the trade for consideration and inquiry only, but not as an absolute proposal 
on the part of the United States government. To this request Mr. Lowell acceded. Thereafter it received considerable attention and discussion in England.

After due consideration the British Board of Trade expressed to the International Literary Association and to the Copyright Association of Great Britain under date of January 14, 1881, its opinion that the scheme proposed in the American draft

"though not all which could be desired, is yet one which might properly be entertained, provided the following modifications and additions be made: (1) That the time within which the British author must intimate his intention of publishing in the United States be extended from three to six months; (2) That the provision requiring the manufacture of books to be in the country of publication be confined to the United States; (3) That all prints or reprints of books by British authors which are published by or with the consent of the author in the United States be freely admitted into the United Kingdom and into all Parts of Her Mrajesty's Dorminions."

The Copyright Association notified the Eoard of Tiade under date of February 12, 1881, that the draft of the proposed copyright treaty with the United States and the modifications and additions proposed by the Board of Trade had been considered and resolutions had been adopted to the effect that while the proposed draft required amendment in matters of detail, it afforded a suitable basis for the negotiation of a treaty with the United States. It was pointed out, however, that the time within which a British copyright owner could obtain copyright in America by republication should not be less than six months from the time of the original publication of his worls, and that the second and third riders proposed by the Board of Trade were inconsistent with and not required by the terms of the draft. The Committee of the Copyright Association at that time consisted of Lord Houghton, Chairman, Sir Charles Trevelyan, Dr. William Smith, Charles Reade, Robert Erowning, James A. Froude, Wilkie Collins, Anthony Trollope, and G. O. Trevelyan, II. P., and the publishers, IIessrs. MIurray, Longman, Macilillan, Chapman, Bentley, Routledge, Rivington, Chappell, Henry Reeve, and Pettee.

Mr. Frederick R. Daldy, honorary secretary, in tronsmitting these resolutions stated that very strong opposition had been displayed to the second and especially the third of the riders proposed by the Board of Trade, which opposition was supported by the Earl of Beaconsfield, J. A. Froude, G. 0. Trevelyan and Herbert Spencer. With respect to the third rider it was pointed out that the question of the admission of foreign printed editions into England was fully considered at the time of the passing of the Copyright Act of August 2, 1875, and that Sec- 
tion 4 of that Act prohibiting importation into Great Britain of Canadian reprints was especially inserted because their admission would prevent English authors republishing their books in Canada, and would thus have rendered the Act practically useless.

The British Board of Trade reported on February 19, 1881, to the Under-Secretary of State, Foreign Office, that having consulted the British authors and publishers on the subject of the draft copyright treaty left by Mr. Lowell with Earl Granville, most of the members were of the opinion that the draft submitted (subject to an alteration of three months to six months for making arrangements for the obligatory American reprint) would afford the basis for a treaty which would be sufficiently advantageous to the authors of the United Kingdom to justify its acceptance by the British government; but the report adds:

"It is scarcely necessary to say that it would be far more satisfactory to Her Majesty's Government and to all classes in this country if a treaty could be negotiated with the United States on the same basis as copyright treaties with other countries, viz., without any condition for the manufacture of English books in America. But if, in consequence of the desire of the United States Government to protect their printers and publishers, it is impracticable to get rid of this condition, the Bonrd of Trade are of opinion that it will be desirable to negotiate on the basis above indicated.

Anxiety was expressed to learn whether the treaty would become law and have effect if approved by the Senate or whether further legislation would be required in the United States to give effect to it. To this inquiry communicated to Mr. Lowell, he responded that the Constitution provides that "a treaty confirmed by two-thirds of the Senators present shall be the supreme law of the land." He added, however, that supplementary legislation might be needed to carry out its provisions in detail, but that this would follow as a matter of course. The Board of Trade also pointed out that

"If it is also provided that books written by American author's and published in America shall be manufactured in England in order to have copyright in England, such provision will require the sanction of Parliament . . and in the opinion of the Board of Trade it is not desirable to insert it."

The International Literary Association further reported to the Board of Trade that after a meeting held for the purpose of discussing the draft convention submitted by Mr. Lowell resolutions were unanimously passed in substance as follows:

"That the draft of the proposed treaty be accepted as a basis for negotiation, subject to the substitution of twelve months for three, as the minimum period within which satisfactory arrangements could be made by British authors for the reproduction of their works in the United States; that the provision re- 
quiring the manufacture of books in the country of publication be confined to the United States, and that the provision to permit prints or reprints of books by British authors to be freely admitted into the United Kingdom and Dorninions, while detrimental to the interests of British authors and publishers, is not required by the United States Govelnment in their draft treaty."

Mir. James Anthony Froude, who was not present at the meeting, wrote that these last matters are questions of domestic legislation which Parliament could deal with, and that "It would be absurd gratuitously and needlessly to bind ourselves to a foreign nation to make this or that internal regulation when that nation does not require us to do so."

Herbert Spencer's consideration of the draft convention brought forth from him an interesting and forceful letter of comment, dated February 7, 1881. Referring to the requirement of republication within three months and the free importation of reprinted books he wrote as follows:

"My chief objection to this extremely short period within which the securing of copyright remains possible, is that while it may, if active efforts are made secure copyright to authors of well-known names who wite popular bools, it will fail utterly to secure copyright to men whose worlis are not of a popular kind, and especially to those who have not yet established reputations. There needs no proof that a new author, especially of a grave book, does not become lmown even at home until after a period of more than three months, more than six months, even more than a year or several years. And if this happens at home still more is it likely to happen abrosd. A new writer not of a popular hind is certain not to secure in America within the prescribed date or anything like it, a recognition such as would lead to negotiations for reprinting his book under the proposed copyright treaty. The result, therefore, must inevitably be that all new witers, and even witers who are not new whose works are of a lind to malie their way but slowly, will receive absolutely no advantage under the proposed arrangement.

"With respect to the third proposed modification I have simply to say that if adopted it will practically result in something approaching to an abolition of copyright. Efforts have already been made in the alleged interests of free trade (which, as was truly said, were in the interests of free booting) to restrict full copyright to so short a period that only popular writers whose book had a quick sale would gain anything under it; and then to substitute for copyright a prescribed snall rate of author's profit, which on books of small sale would bring in very little. And now that which was before proposed to be done directly is sought to be done indirectly. The admission of American reprints of English books is either expected to have the efiect that they will be sold here at considerably lower rates than the English editions, or it is not so expected. If it is not expected, the regulation is a dead letter. If it is expected, then the intention is that the author's home edition shall be competed with and undersold by the American edition, with the efiect of either ex- 
cluding it from the market or forcing a great lowering in price. . . . I am most decidedly of opinion that rather than have any such modification the whole proposed treaty had better forthwith be cancelled, leaving things as they are."

These expressions of the noted author's opinions on the two special matters commented on are interesting with respect to the provisions of our present copyright law in regard to the ad interim copyright protection for English books, and the provisions in the Perkins Bill relating to the control of the importation of foreign reprints of an American author's book.

The international copyright situation was summed up in a contribution of some length to the London Times of March 18, 1881. The anonymous author writes very forcefully and concludes:

"I do not intend to criticize the proposed treaty. It is open to much criticism, but it may be passed over for this reason that, if negotiated, it would be invalid. . . . No international copyright can be binding in the United States unless created by an Act of Congress. . . . The Revised Statutes of the United States' expressly exclude aliens from the benefit of copyright unless those aliens are residents. . . . No treaty can repeal any part of an Act passed by Congress under powers specifically conferred by the Constitution. It is for Congress, then, and not for the treaty-making department of the Government, to amend legislation with regard to copyright so far as aliens are concerned."

Following the publication of this article the English Committee of the International Literary Association announced that having considered at a meeting this article published in the Times and being of opinion that the arguments in favor of the view there expressed (quoted above) were so strong as to make the course of concluding a treaty one of doubtful expediency, they deemed it proper to call the attention of Earl Granville to the question and to express the Committee's view that the difficulty in question appeared to be insurmountable.

FORMULATION OF THE TEXT OF THE INTERNATIONAL CONVENTION

- Up to 1882 numerous treaties for the international protection of authors had been entered into between the different European countries. These, however, were always simply treaties between two countries; no attempt had been made to formulate a treaty or convention embracing a number of coun. tries, and the. United States had not up to this time entered into any copyright treaty.

The idea of a general convention between all countries to secure protection for the works of the authors of each country in all of the other countries, originated with the International Literary Association (Association littéraire et artistique inter- 
nationale) of Paris. This body held annual reunions in the various European capitals, beginning with the conference in Paris in 1878, to discuss legislation, domestic and internationsl, relating to the protection of the works of authors and artists. At the annual meeting held in Rome in 1882 this project for securing general copyright protection throughout the world wos advanced and it was decided as a preliminary step to convolie a conference at Berne, Switzerland, the following year in order that a programme might be elaborated to serve as a basis for an international conference which should embrace: (1) The study of the legislative enactments affecting literary property in all civilized countries; (2) the study of important points of these enactments with a view to unification and the foundation of a union for the protection of literary property; (3) the drawing up of certain articles, clear and concise, setting forth the principles that are most likely to be accepted by the various powers and which should constitute the text of a universal convention.

The proposed conference was held in September, 1883, at Berne, Switzerland, and a project was fully discussed for an international copyright convention to serve as a basis for the formation of a general union of all countries for the protection of the rights of authors. At that conference the Association elaborated a draft for an international copyright convention prepared with a view to its submission for consideration, discussion and signing by the representatives of the governments of all civilized countries. The Swiss Federal Council was requested to transmit this draft to those countries, proposing at the same time that a diplomatic conference be called together to examine and discuss it. The Council promptly accepted this mission, and under date of December 3,1883 , sent to the different countries the procés-verbaus of the International Literary Conference at Berne of 1883 , which document included the draft of an international copyright convention which it was desired should be adopted by all states.

In the letter of transmission signed by the president of the Swiss Confederation, an excellent presentation of the purpose of the union was made in the following statement:

"The protection of the rights of authors of literary and artistic works (literary and artistic property) is becoming more and more the object of International Conventions. It is, in fact, in the nature of things that the work of man's genius, when it has once seen the light, can no longer be restricted to one country and to one nationality. If it possesses any value, it is not long in spreading itself in all countries, under forms which may vary more or less, but which, however, lenve in its essence and its principal manifestations the creative idea. This is why, after all civilized States have recognized and guaranteed by their domestic legislation the right of writer and of artist 
over his work, the imperative necessity has been shown of protecting this right also in international relations, which multiply and grow daily. This need has been supplied by the numerous conventions concluded between the principal States during the last few years. But whatever advantage these conventions present, it must be recognized that they are far from protecting the author's rights in a uniform, efficacious, and complete manner. This inefficiency is without doubt, connected with the divergency of national laws, which the conventional régime has necessarily been obliged to take into account."

Under date of June 28, 1884, the president of the Swiss Confederation sent out a second appeal, referring to the communication of December 3, 1883, and the transmission at that time of the draft for an international convention elaborated with the view of creating a general copyright union. The introductory paragraphs of this latter note state very clearly the purpose of the movement proposed, and this statement is interesting as indicating the gradual development of the idea. President Welti says:

"On that occasion the Council gave expression to the idea that it would be a real gain to establish between the Governments of all civilized countries a general understanding on the principle which is the basis of the Association, and which consists in assuring a protection as efficacious as possible, without regard to political frontiers, to the productions of the human brain in the higher walks of literature and of art. It also thought it expedient to point out that a Diplomatic Conference appeared to be the best manner for ascertaining if and how a common agreement could be arrived at for an international protection to be accorded to authors of literary and artistic works.

"It appears from the notes received, that the fundamental idea of the project is in principle generally admitted, by which all civilized States ought to extend to literary and artistic creations which first see light in another State the protection which they grant to the product of native talent; this general agreement creates thus a broad basis on which to found further steps of progress. The first thing is to study in what way this can be done without interfering too forcibly with the internal legis. lation of particular States, or with existing international conventions. The Federal Council imagines that the prospective conference ought not to pass resolutions of a nature to bind the different States, but that it ought to be of a preliminary nature, and give itself no other duty than that of determining the general principles which have the greatest chance of being realized in the present state of affairs. The provisional results thus obtained would then be submitted to the examination of the Powers, and it would then be seen if it were possible to constitute the projected general Union."

An international conference was held at Berne, September 8 to 19,1884 , in response to the invitations distributed by the Swiss Federal Council, December 1883, and June 1884. There 
were delegates in attendance from Austria-Hungary, Belgium, Costa Rica, France, Germany, Great Britain, Haiti, Italy, Netherlands, Paraguay, Salvador, Sweden and Norway and Switzerland. At this meeting a tentative draft for the proposed international convention was submitted, together with a questionnaire consisting of fourteen inquiries dealing with such copyright matters as length of term of protection; formalities; arrangements of music; rights of translation and representation, and public execution of music; deposit of copies and registration, etc., etc., which matters were taken up seriation and were followed by a debate upon each article of the proposed convention. The full proceedings were reported and printed.

From the prolonged discussion held at this conference a new draft of a convention of twenty-one articles was erolved as well as the text of an additional final protocol, both of which were intended to be submitted to each country for careful scrutiny and returned with comment and criticism for further consideration at the next conference proposed for 1885 .

Two principles of ulterior unification were also enunciated and made public with a request for special consideration and report, namely, that the protection accorded to authors of literary or artistic works ought to endure for the entire life of the author and after his death for a number of years not less than thirty; and that it was desirable to favor as far as possible a complete assimilation of the right of translation to the right of reproduction in general.

The president of the Swiss Confederation under date of October 17, 1884, transmitted to each country for consideration the three documents named, viz: (1) draft of the convention with reference to the creation of a general union for the protection of the rights of authors; (2) the draft of additional articles to that convention; and (3) the draft of Protocole de Cloture. The Swiss government reported on April 21, 1885 by circular note addressed to each country such criticisms as had been received (from France and Belgium only) and gave notice of the forthcoming conference beginning on Monday, September7,1885 , inviting each country to send a delegate or delegates authorized to participate and to sign the Convention, the bases of which had been settled on September 18, 1884, at the conference at Berne.

Seventeen separate countries were represented at this meeting in 1885, including the United States; but the Draft Convention formulated was signed only in behalf of France, Germany, Great Britain, Haiti, Honduras, Italy, Netherlands. Sweden and Norway, Switzerland and Tunis; the representatives of Argentina, Belgium, Costa Rica, Paraguay, Spain and the United States not being authorized to sign. The documents 
formulated and signed at this 1885 conference, comprising the text for a "Convention concernant la Creátion d'une Union internationale pour la protection des oeuvres littéraires et artistiques," were transmitted by the Swiss president to each country, together with a report on the conference and its result; and each country was invited to be represented at a conference to be held at Berne in September 1886, for the purpose of signing the final document as an international convention-the delegates to come with full powers for attaching their signatures to a complete, diplomatic instrument.

A note from the Swiss government dated June 1, 1886, transmitted the printed report of the conference of 1885, and conveyed the information that the draft convention had been favorably received by the different governments addressed, and that a new conference had been arranged for, which was to meet on September 6,1886, for the purpose of signing the document as the text of an actual treaty. The Swiss government again invited attendance of representatives at the 1886 meeting for this purpose. This final diplomatic conference met September 6 to 9,1886 . Twelve countries sent delegates: Belgium, France, Germany, Great Britain, Haiti, Italy, Japan, Liberia, Spain, Switzerland, Tunis and the United States. All of these, except Japan and the United States, signed the formal document which created the International Copyright Union on September 9, 1886. Article 21 of the convention required that ratification should take place within a year, and of the above signatory countries, all but Siberia duly ratified the Convention

The Convention of Berne of 1886, in Article 17, provided that it might be amended, after consideration at conferences to be held successively in the countries of the Union by delegates of said countries; and the final protocol provided that such next conference for revision should take place at Paris between four and six years from the date when the Convention came into effect. This conference was actually held on April 15, 1896, and after the debates of four long and serious sessions, a number of amendments were agreed upon as an "Additional Act," and a "Declaration interpreting certain provisions of the Convention" was accepted. The Additional Act and the Interpretative Declaration were duly signed on May 4, 1896.

The second revision of the International Copyright Convention resulted from the discussions carried on at the International Conference for the Revision of the Berne Copyright Convention, held at Berlin, Germany, October 14 to November 14, 1908. The German government invited not only representatives from the countries within the Union to be present at this conference but also representatives from countries not yet members of the Union. The following fifteen signatory States were 
represented: Belgium, Denmark, France, Germany, Great Britain, Italy, Japan, Liberia, Luxembourg, IIonaco, Norway, Spain, Sweden, Switzerland and Tunis. Of the non-Union countries representatives were in attendance from the following States, nineteen in number: Argentina, Chile, China, Colombia, Ecuador, Greece, Guatemala, Mexico, the Netherlands, Nicaragua, Peru, Persia, Portugal, Rumania, Russia, Siam, Uruguay, Venezuela and the United States.

Active participation in the discussions by representatives of non-Union countries took place only in the case of such countries as were at the time considering adhesion to the convention, for example, Russia and Holland. The power to vote in relation to any proposal discussed was confined to representatives of the countries within the Union and the worling cornmittees-three in number-were wholly made up of representatives from Union countries.

The result of the deliberations at this conference was a complete revision formulated in a single document of thirty articles, taking the place of all the previous instruments of agreement. These conventional acts have remained in force in the Union States which did not ratify the Berlin Convention of 1908, and the States signatory to this last convention were authorized at the time of the exchange of ratifications to declare that they intended upon such or such point, still to remain bound by the provisions of the conventions to which they had previously subscribed.

\section{PROVISIONS OF THE EERLIN CONVENTION}

The Berlin Convention is a distinct advance upon the provisions of the earlier agreements. According to the Berne Convention of 1886 (art. 2) an author of one of the countries of the Union, upon obtaining copyright for his work in the country of origin by a compliance with the conditions and formalities prescribed by its laws, secured copyright (in accordance with their respective laws or treaty stipulations) in the other countries of the Union. That is, an author by virtue of his citizenship in one country and copyright secured thereby, obtained protection in the other countries. The Berlin Convention, on the contrary, proposed a new basis of international union by guaranteeing to an author of any one of the countries of the Union, who published for the first time in any one of those countries, copyright thereby in all the other countries of the Union. Not only is this automatic general protection declared to be not subject to any formalities whatever, but it is expressly declared to be independent of the existence of copyright in the author's work in his own country (arts. 4,5). Thus by the Berlin Convention the authors of each country within the 
Union become, so far as copyright is concerned, citizens of the entire Union, members of a world-wide literary commonwealth. The advantage is secured that the extent of the protection as well as the means of redress in case of infringement are regulated exclusively according to the legislation of each country where copyright is claimed; except as the terms of the Berlin Convention may secure in some of these countries more extended rights (art. 4).

Even an author who is outside of the jurisdiction of any of the countries of the Union, may, by the mere act of having first published his work in one of those countries, enjoy there the same rights as national authors, and in the other countries of the Union the rights accorded by the Convention (art. 6). Thus, for example, an American author who first publishes his work in one of the countries of the Union, secures thereby copyright protection automatically in all the countries of the Union without the necessity of compliance with any formalities whatever and irrespective of whether he has or has not secured copyright for his work in the United States.

As no formalities are required, notice of copyright in the work is not necessary; but the Convention provides that the author's name indicated upon the work in the usual way, or the publisher's name, in the case of anonymous or pseudonymous works, shall be considered sufficient proof of the authorship and copyright (until proof to the contrary) to permit procedure against infringement (art. 15). All infringing copies made in any country where the original is legally protected may be seized as well as unauthorized reproductions coming into that country from another where the work has not been protected, or where the copyright has expired (art. 16).

By the provisions of the Berne treaty authors were given the exclusive right of making or authorizing the translation of their work until the expiration of ten years from the publication of the original (art. 5). The Paris Act amended this to secure to authors the exclusive right of translation for the whole term of protection for the original work, if a translation was produced within ten years after publication; but the right ceased if no translation was produced within the ten years (art. 3). The Berlin Convention secures to authors during the whole term of the copyright in the original work the exclusive right to make or to authorize any translation of it (art. 8).

By the Berne Convention the enjoyment of the rights accorded was made subject to the accomplishment of the conditions and formalities prescribed by the country of origin of the work and could not exceed in the other countries the term of protection granted in the country of origin. By the Berlin Convention the protection is automatic, not depending upon 
compliance with any conditions or formalities, and the term of the copyright is for the life of the author and fifty years after his death. The Convention provides, however, that in case this term should not be adopted uniformly by all the countries of the Union, then the duration of the protection shall be regulated by the law of the country where protection is claimed, but not to exceed the term granted in the country of the origin of the work, and these provisions are made to apply to photographic works, posthumous works and anonymous or pseudonymous works.

Whereas the Berne Convention provided that the manufacture and sale of instruments for the mechanical reproduction of musical airs which were protected by copyright should not be considered as constituting an infringement of the musical copyright, the Berlin Convention provides that authors of musical rorks, whether published or not, shall have the sole right of public performance, and also the exclusive right to authorize (1) the adaptation of these worlis to instruments serving to reproduce them mechanically; (2) the public performance of the same work by means of such instruments.

By the terms of the Berlin Convention the subject-matter of copyright is extended to include the following, not expressly or completely covered by the Berne Convention: works of architecture; choreographic works and pantomimes, and cinematograph productions when the authors of such worls shall have given to them a personal and original character. Adaptations, arrangements of music and other reproductions transformed from a literary or artistic work, as well as compilations from different works are also protected as original worls; and whereas the Berne Convention provided that photographic works should be protected so far as the domestic legislation allowed, the Berlin Convention requires each signatory country to guarantee full protection to all photographic works. Finally, the Berlin Convention was to apply to all worlss which, at the time it went into effect, had not fallen into the public domain of their country of origin.

The above is a very curtailed analysis of the provisions of the Berlin Copyright Convention of 1908-the Convention now in force. But it is hoped that enough has been said to bring out clearly the important developments effected during the forty years' life of the copyright treaty. The original idea was that an author of one of the countries of the Union should obtain exactly the same rights in all the other countries; in other words, that there should be an exact quid pio quo, that being held to be implied in a guarantee of reciprocal protection. But a more liberal construction of "reciprocal copyright protection" now prevails in the legislation and treaty agreements of European 
countries. The next step forward was to agree that an author who had secured copyright for his work in his own country, should be protected in the other countries of the Union; but that the protection in each such country should be that accorded by the laws of the country in which copyright was claimed. The ultimate advance was that any work by an author, citizen of one Union country, should, if his work was published in any other Union country, be protected throughout the Union, even though his work might have failed to obtain protection in his own country. In other words, the great fundamental advance secured was that international copyright relations were no longer based upon a reciprocity which implied an exchange of exactly equal rights and privileges for the same term of protection, but that an author of one country of the Union was to be protected in all of the other countries of the Union by the copyright laws in force in each country.

The original signatory States, as has already been recorded, were ten, as follows: Belgium, France, Germany, including German protectorate countries, Great Britain, including her colonies and possessions, Haiti, Italy, Liberia, Spain, Switzerland, and Tunis. Liberia failed to ratify within the prescribed period but did ratify later. Since the Convention went into effect, up to January 1, 1926, the following new members have been added to the Union: Austria (October 1, 1920) ; Brazil (February 9, 1922) ; Bulgaria (December 5, 1921) ; Czechoslovakia (February 22, 1921) ; Free City of Danzig (June 24, 1922); Denmark, including the Faroe Islands (July 1, 1903); Greece (November 9, 1920) ; Hungary (February 14, 1922); Japan (July 15, 1899); Liberia (October 16, 1908); Luxembourg (June 20, 1888) ; Monaco (May 20, 1889); Morocco-except the Spanish zone (June 16, 1917); The Netherlands (November 1, 1912) ; Norway (April 13, 1896); Poland (January 28, 1920); Portugal, including her colonies (March 29, 1911); Sweden (August 1, 1904). In addition France ratified originally in behalf of her colonies and Algeria, and on August 1, 1924, in behalf of Liban and Syria; and the Netherlands in behalf of the Netherlands, Indies, Curaçao and Surinam, ratified on April 1, 1913. The original ratification by Great Britain included India and a number of small possessions. All the self-governing dominions are now also included: Canada, Newfoundland, Australia, New Zealand and the Union of South Africa, while ratification by Great Britain in behalf of Palestine was made on March 21, 1924.

\section{PARTICIPATION OF THE UNITED STATES IN THE COPYRIGHT CONFERENCES}

The United States as has already been indicated neither 
signed the preliminary drafts nor the final text of the International Copyright Convention. The official correspondence between Switzerland and our Department of State is not only interesting but valuable as indicating and explaining our anomalous position in relation to international copyright.

In response to the Swiss note of invitation of December 3, 1883, Hon. Frederick T. Frelinghuysen, Secretary of State, replied under date of January 24, 1884, in part as follows:

". . . The question of international copyright has for many years attracted the attention of this Government. While disposed in principle toward the proposition set forth that the author of a literary or artistic work, whatever be his nationality and whatever the place of reproduction, should be everywhere protected on the same footing as the citizens and subjects of each nation', this Government sees grave difficulties in the way of a general arrangement to embrace all countries in one scheme of copyright protection. The difference of tarifis of the several countries, and the fact that many other industries besides that of the author or artist are concerned in the production and reproduction of a book or work of art, must be borne in mind when considering any plan by which the originator of the work is to be vested with the right to produce or to prohibit its production in all other.countries. . . They place an author in a very different position from a painter or sculptor, whose personal handiwork goes upon the market. These points are mentioned not as expressing results reached by this Government, but as the obstacles to the adoption of an international copyright with a country whose tariff differs from our own."

The agitation for international copyright which began in 1878 upon the publication and distribution of the draft for a copyright treaty between the United States and Great Britain submitted by MIessris. Harper \& Brothers to the Secretary of State had about reached its culmination at this date, 1881. The American Copyright League had been established with George P. Lathrop as secretary, and an executive committee consisting of the following eighteen well-known authors: John Eigelow, H. H. Boyesen, Noah Brooks, Robert Collyer, Howard Crosby, Edward Eggleston, Sidney Howard Gay, Richard Watson Gilder, Parke Godwin, George Walton Green, Laurence Hutton, Brander Matthews, Bishop Potter, A. Thorndilie Rice, R. H. Stoddard, Bayard Tuckerman, Charles Dudley Warner and Professor Youmans.

Under date of January 18, 1884, a printed letter of inquiry signed by the secretary and each member of the executive committee of the American Copyright League was addressed to the Secretary of State. This letter stated that at a meeting of the abovi-named committee, it was voted on January 11, 1884, "to urge the Department of State to complete an international treaty with Great Britain, securing to the authors of each coun2- "he full recognition of property rights in each country." 
The letter then goes on to express its objections to the proposals of the publishers' copyright treaty submitted, (the HarperAppleton draft) because it proposes "limitations as to time of publication and imposes conditions as to manufacture that belong to regulations of trade and tariff and not to authorship." But expressing recognition of the necessity for some immediate relief from the existing situation "which inflicts serious injury upon, and promises still more to impair, literary production in this country" the letter indicates a willingness to accept "what can be obtained as a relief, while waiting for the establishment of simple international justice in regard to this sort of property."

To this appeal Secretary Frelinghuysen replied at length on January 25, 1884.

After acknowledgment of the letter received, he wrote in part as follows:

"In answer to your request to be informed (if proper) 'whether the negotiations for this treaty are likely soon to be renewed, or for some form of copyright treaty,' I may observe that the pending negotiation has not been interrupted, but that the diverse views of the authors and publishers of this country which were elicited in response to the confidential inquiries addressed to them by this department on March 18th, 1882, are still under consideration. . . . The difficulty in the way of negotiating a formal copyright treaty with any foreign country is that the copyright laws of the two countries are usually so different that a detailed reciprocal code cannot be agreed on. Such a codified treaty necessarily puts the foreign author on a different footing from the home author, more privileged in some things it may be, and less so in others. And this difficulty is enhanced when-to quote the language of the Executive Committee's letter-such detailed stipulations 'put limitations as to time of publication and impose conditions as to manufacture that belong to regulations of trade and tariff, and not to authorship.'

"I am satisfied that a simpler solution of the question could be effected by some means which will give in each country to the foreign author the same right as a native author enjoys. The domestic copyright law does not attempt to legislate upon the relations between an author and his publisher, and it is not easy to see why an international compact should legislate upon a point which in each country is left to the course of trade. I think the foreigner owning a copyright should have here the same privileges as our own citizens, provided our citizens have in the foreigner's country the same rights as the natives thereof; and thereupon I would leave to the mutual convenience of the holder of the copyright and the publisher the adjustment of their contract, and leave to the tariff the task of protecting the paper-makers, type-founders, printers, and other artisans who join in producing the book as a marketable article."

Later on, the question of representation by the United States was taken up by Mr. M. J. Cramer, who wrote from the United 
States legation at Berne on April 9, 1884, to the Secretary of State calling attention to the fact that the Swiss Federal Council had sent an invitation to forty-one governments for representation or participation in a diplomatic conference to be held at Berne in September 1884, for the purpose of promoting if not concluding an international convention for the protection of literary and artistic property. Mr. Cramer reported that he had been credibly informed that a number of foreign governments had accepted the invitation "including Great Eritain, which has delegated its Minister at Berne to be present, though not invested with authority to vote on internationally binding resolutions." He suggested that the United States should be represented at the conference in a manner somewhat similar to that of Great Britain. In his later note of August 29 he announced his intention to attend the conference as a private spectator and to inform the Secretary of the result; but in his note of October 1 he reported that as the sessions were not public he did not attend.

To Mr. Cramer's note of April 9 MIr. Frelinghuysen responded on May 28 that the Swiss circular letter of December 3, 1883, was not understood to have been a distinct invitation to attend the copyright conference, but rather a request for a preliminary expression of views as to the expediency of holding an international conference on the subject. He referred to his note of January 24 (quoted abore) as indicating the difficulties in the way of a just, common arrangement, and as intimating that the suggestion as a whole was viewed with disfavor.

A note by the Swiss president dated June 28, 1884, referring to the former note of December 3, 1883, reiterated the purpose in view, and added that the Swiss Federal Council would invite representatives to a conference proposed for 1884, in order to carry forward that purpose; and on August 22, 1S84, the Swriss president transmitted a printed programme intended to serve as a basis for the deliberations of the international conference arranged to meet at Berne on September 8, 18S4, asling that the United States delegates to that conference be given instruetions on the different points touched on in the progiamme, and explaining that the result of the deliberations of the conference would afterwards be submitted to the consideration of the different governments to determine if it could be turned into a diplomatic act.

The Acting Secretary of State (MIr. Wr. Hunter) under date of September 18, explained that the United States government had not understood this presentation of the matter by the Swiss government as a formal invitation to participate in the international conference and consequently no delegate was appointed. The Secretary added: "You can assure your Government that 
we are, however, interested spectators of the conference, in view of the importance of the copyright question in this country." To this the Swiss Minister responded on September 23, 1884, that the Swiss Federal Council by its circular of June 28, 1884, did formally invite the governments to send delegates to the convention which was to meet at Berne on September 8, 1884, and that the invitation was transmitted in the Swiss note of July 12, preceding. The result was that at this conference held at Berne in September 1884, the United States was not represented. President Arthur reverts to this in his message of December 1, 1884, explaining why no delegate was sent:

"The question of securing to authors, composers, and artists copyright privileges in this country in return for reciprocal rights abroad is one that may justly challenge your attention. It is true that conventions will be necessary for fully accomplishing this result, but until Congress shall by statute fix the extent to which foreign holders of copyright shall be here privileged, it has been deemed inadvisable to negotiate such conventions. For this reason the United States were not represented at the recent conference at Berne."

A Swiss circular note, dated October 17, 1884, was transmitted by the Swiss Secretary of Legation at Washington on November 21, 1884, to the Secretary of State. It contained the revised texts of the copyright documents-the draft of a convention respecting the formation of a general union for the protection of the rights of authors, etc. It was followed by the Swiss note of April 24, 1885, reporting briefly on the work of the 1884 conference and announcing the conference for 1885, and inviting the Secretary to send a representative authorized to sign the convention, the bases of which were settled at the former conference on September 18, 1884.

To this Secretary Bayard responded on May 21, 1885, as follows:

"I have the honor to inform you that as the question of international copyright has been and still is pending in the Congress, this Government does not feel justified in precluding its free discussion by entering into an international engagement in the nature of a formal general treaty as proposed by your Government before the will of Congress in the matter shall have been manifestęd.

Nevertheless, as the subject is one in which the Congress and the people have shown an interest, it would be very gratifying to the Government of the United States to take part in the consultative deliberations of the proposed conference and to profit by the comparison of views which will doubtless be fully drawn out on that occasion. If the attendance of delegates for this purpose (with the reserved option of ultimately adhering to the results which may be attained if they comport with the 
interests and policy of this Government) be found agreeable, a delegate or delegates will be designated on behalf of the United States with limited functions as above stated."

The reply of the Swiss Minister was that he had no doubt that his government would receive with satisfaction the Secretary's proposal, and on June 22, he reported its acceptance "with great pleasure." Thereupon IIr. Eoyd Winchester, the United States Minister to Switzerland at that time, was authorized to attend the session in a note from the Acting Secretary of State, Mr. James D. Porter. MIr. Porter repeated at length to $\mathrm{MIr}$. Winchester the explanation which Secretary Bayard had made to the Swiss Minister at Washington in his note of Miay 21, 1885, quoted above. The note to Mr. Winchester informed him that in view of the Swiss Minister's assurance that the conference would be pleased to accept a cooperative, consultative delegate from the United States, he was requested to attend the international copyright conference to be held in Berne in September as the United State delegate, but to limit his action to participation in the deliberations of the conference only, and at the close of the conference to malie a full and careful report of its proceedings to the Department of State.

In the session of the Conference of September 17, 1885, MIr. Winchester made a statement in which he explained his peculiar position, but he assured the conference that the United States was neither unmindful of the high and important character of the conference nor indifferent as to its results. He followed in his explanation very closely his letter of instructions from Secretary Bayard-often using the same language, and in conclusion said:

"However, I feel free to say this much, that I believe the United States Government is kindly disposed in principle towards the proposition that 'the author of a literary or artistic work should be everywhere protected on the same footing as the citizens or subjects of each nation.' It is true grave difficulties may confront such an arrangement, but in a spirit of mutual concession they should be made to yield to an equitable, just, and enlightened international adjustment."

Mr. Winchester made a detailed report to the Secretary of State under date of October 5,1885 . He stated that in attending the conference as a consultative delegate he felt that he was placed at a great disadvantage, explaining the situation as follows:

"Nearly all the countries represented in the conference were participants in the first similar conference held here last year, and were represented substantially by the same delegates; of course, these gentlemen had thoroughly familiarized themselves with the subject-matters to be considered, and especially in all 
the bearings affecting their respective local interests. In the discussion and preparation of the numerous and important details involved they were prepared not only to make suggestions, but properly equipped for intelligent effort to secure their adoption. These suggestions naturally partook more or less of a selfish purpose. It was a question which had never engaged my attention. Your dispatch contained no intimation as to any special points or features to be watched, or as to any line of ac. tion on the part of the conference which would most probably command the approval of the United States."

This matter was again brought to the attention of Congress in President Cleveland's Annual Message of December 8, 1885, in the following paragraph:

"An international copyright conference was held at Berne in September, on the invitation of the Swiss government. The envoy of the United States attended as a delegate, but refrained from committing this Government to the results, even by signing the recommendatory protocol adopted. The interesting and important subject of international copyright has been before you for several years. Action is certainly desirable to effect the object in view; and while there may be question as to the relative advantage of treating it by legislation or by specific treaty, the matured views of the Berne conference can not fail to aid your consideration of the subject."

The Swiss president wrote the Secretary of State on November 6,1885 , reporting on the results of the conference of that year, the countries represented and those signing the draft convention, etc. Printed copies of the resulting official documents were also transmitted with a request for the favorable consideration of them as final texts, not subject to further amendment, and the Secretary of State was invited to be represented at the conference of 1886. A further note dated June 1, 1886, informed the Secretary of State that the convention draft had met with a favorable reception, and that the meeting of the final conference was fixed for September 6, 1886, at Berne, and conclúded as follows: "We are glad to believe that your Government will participate in it, and with this hope we request your Excellency to inform us of the name of your delegate, and to furnish him with the powers necessary to sign the convention."

To this Secretary Bayard responded at length on June 29, 1886, as follows:

"The important question of international copyright has been before the Congress of the United States for several years, and a legislative measure is there pending, which will authorize the conclusion of international treaties on the subject. The matter has not advanced far enough in the legislative channel to enable the Executive to act with the desirable knowledge that the course it might adopt would be likely to agree with the views of Congress. Moreover, the Constitution of the United States enumerates among the powers expressly reserved to Congress that to 'Promote the progress of science and the useful arts by securing for limited times to authors and inventors the exclusive 
right to their respective writings and discoveries,' which implies that the origination and limitation of measures to those ends rests with the legislative rather than the treaty-maling power. . .

"All these considerations have necessarily deferred a reply to the invitation of the High Federal Council of November 6 , 1885 ; and the continued pendency of measures in Congress make it, as yet, impracticable for the United States to depute a plenipotentiary to attend the forthcoming conference at Berne for the purpose of signing the proposed international copyright convention. The attitude of this Government toward the project is merely one of expectancy and reserve. In principle it favors the plan but without determinate views as to the shape it should assume, and is at present unprepared to suggest modifications which might conform the convention to the legislation which Congress may hereafter deem appropriate. Without feeling authorized to join in the proposed convention as a full signatory, we do not thereby wish to be understood as opposing the measure in any way; on the contrary, the Government of the United States reserves, and without prejudice the privilege of future accession to the international convention should it become expedient and practicable to do so, under the provisions of article 18 thereof.

"To exhibit its benevolence toward the principle involved, the Government of the United States will take pleasure in instructing its representative at Berne, MIr. Boyd Winchester, to attend as a delegate the conference of September next under the reserve herein indicated. IIr. Winchester will not be empowered to sign the international convention on behalf of the United States, but he will be authorized and instructed to declare to the Conference that the United States, not being parties to the proposed convention, reserve their privilege of future accession under article 18 thereof."

Mr. Winchester's name appears, therefore, in the list of delegates present at the 1886 Conference. In the opening session on September 6, he made a formal statement explaining the attitude of the United States in relation to the proposed International Copyright Convention in much the same language used by $\mathrm{Mr}$. Bayard in his note of June 29,1886 , and referring to the paragraph on international copyright in President Cleveland's message of December 8,1885 , quoted his statement that "action is certainly desirable to effect the object in view." $\mathrm{He}$ concludes with the enunciation, "That the brain that creates is entitled to and should receive its just and full compensation, is a sentiment having its origin in the natural sense of honesty."

At the close of $\mathrm{MIr}$. Winchester's remarls the president of the conference thanked Mr. Winchester and assured him in the name of the Conference that the accession of the United States would be received at any time with joy by all the contracting states. In his report MIr. Winchester stated that the non-participation of the United States as one of the original signatory powers of the convention was a matter of free and arowed re- 
gret, there seeming to be but one sentiment, that no international copyright union could be complete without the United States and that great solicitude was expressed that the convention should contain no stipulations of a nature unacceptable to the United States.

In his final report on this international conference to the Secretary of State Mr. Winchester was pronounced in his expression of approval of full international protection for authors, and of an international convention that would secure such protection to its utmost extent. The formulation and expression of his views of this advance in copyright protection are so excellent that it seems worth while to rescue his statement from the graveyard of official documents.

1

"I may be permitted to express the opinion that the Government of the United States cannot afford to stand before the world as the only important and deeply concerned power persistently refusing to do common justice to foreign authors, and that it may be justly anticipated, that the Copyright Union being formed and acceded to by the more important European countries, it will before long feel it difficult to abstain from becoming a party to it also, and Congress will proceed to pave the way to the adhesion of the United States to the Union. There are large interests invested on the faith of the existing law that should receive proper consideration and be equitably dealt with. In the absence of international copyright, general and uniform, just and full compensation for literary or artistic property is out of the question, and the injustice is all the more conspicuous in view of the fact that the discrimination made against authors is not made against any other class of foreigners. Literary property is the only kind of personal property not protected by our law when the owner is not a citizen of the United States. Even to the foreign owners of patents and trade-marks, which are so analogous to copyright, protection is accorded. The question should be solved in an acceptance of the moral view, that if it be right for a native citizen to have copyright in the productions of his intellect, it is equally right for an alien author to have the same property right recognized and protected.

"Outside of the ethical or abstract rights, copyright is a modern development of the principle of property which every man of delicacy and honor must commend, regardless of the obscurity which may envelope its origin. The sophistical plea that the culture and education of the American people is to be imperilled or books to be placed beyond the reach of the masses by international copyright should be disregarded. If necessary, the reverse could be supported by many practical considerations. This, however, is not the question now submitted. The primary matter is to do what is right and just. In the long run it is the only safe course and proves the most profitable as well to nations as to individuals. Why should we force our native authors to suffer a great injustice from being forced into unusual competition with the wrongfully appropriated labor of 
foreign authors? The spirit of literary ambition and activity is daily becoming greater and more diffusive among our people, quickening and nourishing into life a vast and valuable native literature. It is impossible to determine the elements which must conspire to form and build up a native literature."

Again President Cleveland felt it desirable to direct the attention of Congress to this matter in his Annual Miessage of December 6, 1886, pointing out that "The drift of sentiment in civilized communities toward full recognition of the rights of property in the creations of the human intellect had brought about the adoption by many important nations of an International Copyright Convention," but inasmuch as Congress was charged with the power to legislate on copyright

"this Government did not feel warranted in becoming a signatory pending the action of Congress upon measures of international copyright now before it; but the right of adhesion to the Berne convention hereafter has been reserved. I trust the subject will receive at your hands the attention it deserves, and that the just claims of authors, so urgently pressed, will be duly heeded."

REVISION OF THE CONVENTION AT PARIS, 1896

Twenty-six countries were represented at the first conference of revision at Paris in 1896, including the United States, whose delegate was MIr. Henry Alexander, described as Counsellor of the United States Embassy at Paris. He is not referred to in the report of the conference as having made any statement or otherwise having taken part in the proceedings.

REVISION OF THE CONVENTION AT BERLIN, 1908

After twelve years, in 1908, the second conference of revision was called to meet in Berlin on October 14. The German government, issuing the invitations, included not only all Union countries but non-Union countries as well; and explained that the delegates of non-Union nations attending the proceedings of the conference would have full freedom of action, as was the case at the Paris conference, and that they were privileged to confine themselves to following the discussions without taking any stand with regard to them. The conviction was expressed that whatever might be the position taken by the non-Union nations or their laws towards the copyright question, their participation in the conference could at all events contribute towards arousing and increasing the interest of their delegates in the Berne Union and its beneficial work.

In response to the invitation to send a representative from the United States, the Honorable Elihu Root, Secretary of State, on May 22, 1908, issued a certificate designating the Register 
of Copyrights as a "delegate on the part of the United States to the conference of the International Union for the protection of Works of Literature and Art to be held at Berlin, October 14, 1908"; it being understood that the delegate was to attend the conference solely for the purpose of observing the proceedings and making such notes and report as would be useful to the government. At the beginning of the conference, however, an expression was asked for as to the position of the United States in relation to the International Copyright Union and explanatory of the attendance of its representative.

In responding the Register of Copyrights made the following statement:

"The Government of the United States again finds it impracticable to send a delegate authorized to commit the United States to actual adhesion at this time to the Berne Convention. Nevertheless, it has been felt that the representation of the United States, even within the limitations indicated, might be beneficial: first, to indicate the sympathy of our Government with the general purposes of the International Copyright Union; second, to secure such information regarding the proceedings of the conference as might prove valuable; and third, to place (by means of such representation) at the disposal of the conference authoritative knowledge as to the facts of copyright legislation and procedure within the United States-information which it is hoped may be of use to the members of the conference in their deliberations.

"Some of the questions to be discussed here are pending before the Congress of the United States in the copyright bill now under discussion. I wish to avoid, therefore, taking any position in regard to the special matters in question-any position which might tend to commit the United States in advance to any line of policy which might embarass the legislative branch of the Government of the United States in taking such action regarding these matters as it may finally deem advisable. But within that limitation-with the most hearty and cordial expression of my sympathy for the ends and purposes of the Berne Union-I beg to place myself at the service of the conference."

Prof. Renault, the president at the working sessions of the Conference, in his report to the conference in regard to the representation from non-Union countries, spoke as follows in reference to the United States:

"Mr. Thorvald Solberg, chief of the Copyright Office in the Library of Congress, has on his part read a declaration which does not allow us to entertain the same hopes as the preceding declarations, [in regard to Holland and Russia] but which has nevertheless its interest as coming from a country which plays so great a role in literary and scientific production. The Government of the United States manifests its sympathy for the end sought in general by the Berne Union and desires to be informed on the deliberations of the conference. Mr. Solberg, in making so long a journey for the sole purpose of being among us, has given a proof of his personal interest and of his admira- 
tion for our work to which he now contributes, and will contribute, to make known in his country; we can but be grateful to him therefor. The foregoing statements have a value from a double point of view-they allow us to hope for a new extension of our union; they show us that the character of our new regulations must be sufficiently pliable to be adapted to very diverse situations."

It is expected that a third conference of revision moy talie place in Rome shortly. When it does the question of participation by the United States will again be brought into question. Meantime favorable action may have been taken by Congress upon the proposals to permit the United States to enter the International Copyright Union contained in the two copyright bills now before it for further consideration.

\section{THE PRESENT SITUATION}

Forty years have elapsed since the United States government was invited in 1886 to adhere to the international copyright convention creating the Copyright Union. Up to that date, despite persistent agitation for international copyright extending over a long period of time, no steps had been talien with respect to the protection in the United States of the worls of foreign authors. Since 1886, also, the question of copyright has been much discussed in the United States, and some advance has been made, not only in relation to domestic copyright legislation but also with respect to internationel copyright. The socalled International Copyright Act was approved on Mireh 3, 1891, and by the legislative expedient of merely strilking out from the Revised Statutes relating to copyright, the gualifying words "Any citizen of the United States or resident therein" in the sections according protection to "the author, inventor", designer, or proprietor of any book," etc., copyright protection was extended to alien authors in the United States. Thus, after the lapse of a full century of time, the abrogation was secured - of that section in our first Federal Copyright Act of May 31, 1790, which authorized the appropriation of the worls of foreign authors without regard to the property rights which such authors might be supposed to possess in their own worls. This section (5) of the Act of 1790 read as follows:

"That nothing in this Act shall be construed to extend to prohibit the importation or vending, reprinting or publishing within the United States, of any map, chart, book or bools, written, printed, or published by any person not a citizen of the United States, in foreign parts or places without the jurisdiction of the United States."

This extension in 1891 of the copyright protection within the United States to foreign authors was, however, restricted by 
the imposition of the much-discussed requirement of the manufacture of the author's work within the limits of the United States as a condition to be complied with before copyright could be obtained. That obligation to print brought with it, as a corollary, the prohibition of importation of authorized copies of the foreign author's book, and this requirement of manufacture and prohibition of importation are both still operative under the provisions of our present copyright legislation. Since the Act of 1891 there have been sixteen legislative enactments affecting copyright, including the important act of general revision of the copyright laws approved March 4, 1909. But no one of all those enactments has had any bearing upon international copyright protection except that the textual amendment made in section 15 of the Act of 1909 by the insertion of the words "except the original text of a book of foreign origin in a language or languages other than English," serves to release the foreign author, who publishes his work in some language other than English, from compulsory manufacture in the United States in order to secure protection.

Whether, during the passage of all these years, there has been a gain in sentiment in favor of entry into the Copyright Union, it is not possible to say; but as two bills were introduced into the present Congress proposing the entry of the United States into the Union, and as both bills are still pending and will come up for discussion during the next session there will probably be an opportunity to ascertain fairly accurately what kind of support and how much support a proposal to enter this Union may receive. One of these bills, the Perkins Bill (H. R. 5841), was originally introduced on January 2, 1925, and reintroduced without change on December 17, same year. The other bill (H. R. 10434) was introduced in the House of Representatives on March 17, 1926, by Hon. Albert H. Vestal, Chairman of the House Committee on Patents.

The contents of this latter bill are largely the same as the earlier one, fully two-thirds of its text having been taken over from H. R. 5841 without change. Nevertheless there are very considerable and serious differences between the two bills. Of the text of the Perkins Bill 150 lines have been omitted in th Vestal Bill, while there is new text matter added in the latter bill amounting to 320 lines. Both bills propose general revision of our copyright laws and new legislation to cure defects which have been brought to light under the operation of the Copyright Act of March 4, 1909, and both start out with the declaration that copyright is secured for all the writings of authors from the time of the making of their works and that such copyright shall vest in the author of the work immediately 
upon its making and shall not depend upon the accomplishment of any conditions or formalities whatever.

It is not proposed in this article to deal with such amendments of our copyright laws as are primarily applicable to our own affairs, but only to consider proposals in the bills in so far as they have to do with our entry into the International Copyright Union.

The following important provisions of law are incorporated in both bills, and for the most part in identical language: The President is authorized "to effect and proclaim the adhesion of the United States" to the conrention creating the International Copyright Union. To make this efiective and secure entry by the United States into the Union, such amendments of the existing copyright laws are proposed as will permit adherence to the articles of convention upon which the Union is founded. These articles of convention require that protection shall be accorded to works of architecture, and to choreographic worlss and pantomimes, and these productions have been added to the list of works protected by our present laws.

Copyright in the United States for works by foreign authors is directly provided for and the duration of such copyright is limited to the date when the foreign work has fallen into the public domain in the country of origin. Provision is made to safeguard any person who has "taken any action in connection with the reproduction or performance (in a manner which at the time was not unlawful) of any such work whereby he has incurred any substantial expenditure or liability," against action to restrain him. The Perkins Bill adds, "unless such foreign author agrees to pay him such compensation as, failing agreement, may be determined by arbitration."

A general term of copyright is proposed in accord with the term of protection provided by the international copyright convention of 1908, namely, the life of the author and fifty years after his death. This proposal to extend the term of protection is qualified however by the express provision "that the duration and termination of the copyright protection in the United States for all works shall be governed by the provision of this Act," and "that the duration of copyright in the United States shall not in the case of any foreign work, extend beyond the date at which such work has fallen into the public domain in the country of origin." Special provisions are made as to the term in the case of a work by joint authors and for posthumous works, or for works the copyright of which is first owned by "an employer for hire," or for composite or cyclopaedic works, or for compilations, adaptations or arrangements of music, and, finally, for newspapers and periodicals; in 
all of which cases the term proposed is fifty years from the date of the first publication of the work.

The provisions of both bills which extend copyright to foreign authors are alike in substance, but the Vestal Bill specifically extends copyright to an unpublished work when it is created by a citizen or subject of a foreign country adhering to the International Copyright Union. The Perkins Bill contains a provision (not included in the Vestal Bill), to the effect that works by foreign authors in which copyright is subsisting in any country of the Union at the date of the proclamation of our entry into the Union, and works made or published after that date, shall be protected in the United States from such date.

Deposit of copies, registration of claims of copyright, and the insertion of notice of copyright, are all abrogated so far as they are conditions to be complied with in order to obtain copyright. But it is made optional with the author or copyright owner to do any of these things and expressly provided that any foreign owner of a copyright for any work in one of the countries of the Copyright Union, "may, if he so desires, register his claim of copyright in such work for the United States by depositing a copy of the work in the Copyright Office at Washington, together with the prescribed application for registration." In the case of published works, the interests of the Library of Congress are safeguarded by requiring deposit as now but "not as a condition for securing copyright but for the use of the Library of Congress," and it is expressly provided that such deposit of copies as is required by the provisions of the bills "shall not be obligatory in the case of any work whose author is a citizen or subject of a foreign country which is a member of the International Copyright Union, unless and until such work, if it be a book, shall have been republished in the United States under an assignment of the copyright for the United States or under a license to print and sell such book in the United States."

Under our present law the insertion of a notice of copyright in the form prescribed by the statute is a condition precedent to securing copyright protection. Both bills expressly provide that no notice of copyright shall be required, but permit the use of some warning notice by the author or copyright owner of the work, or by the assignee or licensee of any special right pertaining to the copyright in the work, if so desired.

The Perkins Bill further provides explicitly that foreign authors shall have within the United States "the same rights and remedies in regard to their worlks which citizens of the United States possess under this Act and for the period of copyright protection prescribed by this Act," this being implied but not expressly stated in the provisions of the Vestal Bill. 


\section{REQUIREMENT OF AMERICAN MIANUFACTURE}

In this analysis of the provisions of the two coprright bills for the general revision of the copyright laws of the United States, we now come to a consideration of some of the vital and fundamental variances between the two measures.

It is a fundamental article of the International Copyright Convention that copyright protection shall not be conditioned upon compliance with any formalities. The requirement of American manuiacture for bools, lithographs, and photo-engravings, contained in our Copyright Act of March 3, 1891, and re-enacted on IIarch 4,1909 , has been and is the most serious bar to entry by the United States into the Copyright Union. These manufacturing requirements are therefore eliminated entirely in the Perkins Bill, as well as the affidavit of such American manufacture prescribed by the Copyright Act of 1909. The bill further directly provides that after the date of the President's proclamation authors of the Copyright Union "shall have within the United States the same rights and remedies in regard to their works which citizens of the United States possess," and adds that "the enjoyment and exercise by such foreign authors of the rights and remedies accorded by the provisions of this Act shall not be subject to the performance of any formalities." It is, of course, understood and admitted that we cannot enter the International Copyright Union at all if these burdens are imposed upon foreign authors of countries within the Union. The Vestal Bill, therefore, in its section 28, providing that printed books and periodicals shall be printed from type set within the United States, etc., adds that the "Said requirements shall not apply . . . to works by foreign authors." It is contended that this exemption is sufficient to meet the provision of the Convention, and that imposing these burdens upon our own authors will not debar us from entry into the Union. But there is then proposed an obligation upon our own citizens from which foreign authors will be released.

The question has been raised whether this requirement of compulsoiy printing is sufficiently profitable to the printing trades to be so strongly insisted upon; and in this connection it is of decided interest and well worth while to go baek a quarter of a century for an official expression as to the efrect of the manufacturing provisions after they had been in force for nearly ten years.

About ten years after the Copyright Act of 1891 was passed, the Commissioner of Labor, Dr. Carroll D. Wright, under authority of the senate resolution of January 23, 1900, submitted to the Senate a "Report on the effect of the International Copyright Law." There was published in the New York 
Nation in the early part of 1901 a series of three articles containing a summary of the testimony elicited. The third article summarized the expressions of opinion, based upon the test of nine full years of practice under the Act, of the effect of the compulsory requirement of American manufacture in the case of books. While a certain number of printers and publishers, directly or indirectly indicated their approval of the type-setting provisions of the Act of March 3, 1891, a much larger number, including such well-known firms as the American Book Company, Burrows Brothers Company, the DeVinne Company, D. C. Heath \& Company, Henry Holt \& Company, Little, Brown \& Company, McClurg \& Company, L. C. Page \& Company, G. P. Putnam's Sons, and the F. A. Stokes Company, insisted that the stipulation had been of little or no use either to printer's or to publishers, and that it should be done away with on the grounds:

"(1) That it is no longer needed for the protection of printers, owing to composition being cheaper here than abroad; (2) that electrotyping is not only cheaper here but better; (3) that there is no sufficient advantage in the importation of English editions with the present duty; (4) that the tariff laws afford ample protection against the importation of sheets; (5) that the special tastes of American book-buyers can be trusted to compel manufacture here to meet requirements; (6) that it involves a wrong principle to compel the producer to do his manufacturing with one set of printers rather than another; (7) that instead of forcing books to be manufactured in this country, it really forces foreign books to get along without copyright protection; (8) that it is unjust to the book-buyer; (9) that it is a tax on the public; and (10) that it is an unfair exchange to receive unrestricted protection for our authors abroad and impose this onerous burden on foreign authors here."

It was noticeable that approval of the obligatory type-setting was mainly confined to the firms (fifteen in number) who were unfavorable to international copyright.

The reasons advanced by leading publishers with respect to this still much debated type-setting requirement are of interest and value. Little, Brown \& Company held that copyright should be extended to citizens of foreign countries as a matter of justice and without that requirement; D. C. Heath \& Company thought international copyright was a matter which should not be mixed up with tariff laws; L. C. Page \& Company believed the manufacturing requirement had deterred foreign authors from attempting to secure copyright and that it should be given up; Small, Maynard \& Company argued that if copyright is a just principle, it should be applied without the manufacturing restriction; A. C. McClurg \& Company believed that it worked very great hardship to publishers and authors; the American Book Company held that it was in conflict with na- 
tural laws of trade and largely defeated its own purpose; George Haven Putnam, always a staunch supporter of international copyright, was emphatic in his declaration that "The manufacturing condition should be eliminated from the law. It is entirely illogical to couple with the recognition of the right of copyright a condition forcing the producer of the copyrighted property to do his manufacturing with one set of printers or another. As far as it is necessary to guard American manufacturing interests, these should be cared for under the tariff system." Frederick A. Stokes Company advocated the removal of the stipulation. P. Blaliston's Son \& Company, Lea Brothers \& Company and P. W. Ziegler \& Company, all of Philadelphia, together with some others, averred their firm belief in the advantage of the type-setting clause.

This abrogation of the requirement of American manufacture of copyright books logically requires the elimination of the restrictions on the importation of copies of the authorized edition of the foreign author's book, now contained in our copyright laws, and the Perkins Bill proposes doing away with all of these restrictive provisions. Prior to 1891 our copyright law's contained no provisions prohibiting inportation except in the case of pirated copies. Such exclusion of tincuthorizcd copies is essential to copyright protection and the Perkins Bill expressly so provides, and that such illegal importation shall be deemed an infringement of the copyright. When the requirement of manufacture in the United States was inserted in the Act of March 3, 1891, in order to give force and full effect to such compulsory remanufacture, the Act also prohibited the importation of copies of the authorized foreign editions of works reset in America, "or any plates of the same not made from type set, negatives, or drawings on stone made within the limits of the United States." In the 1909 Copyright Act, the compulsory manufacturing provisions were re-enacted, as well as the prohibition of importation of copies of the authorized original edition; but this prohibition was by that Act confined to bools, and importation was permited on behalf of individuals, libraries and institutions of "one copy for use and not for sale."

In the Perkins Bill there has been incorporated a provision to permit the American copyright owner who authorized a foreign reprint of an American author's book to enter into an agreement, if desired, stipulating that copies of the foreign reprint-commonly much cheaper in price than the original American edition-shall not be imported into the United States, provided such agreement shall be put on record in the Copyright Office and the Treasury and Post Office shall have been notified that importation of such copies is in contravention of the agreement. 
It will be observed that this possible prohibition of importation of the reprint of the copyright book, is an entirely different matter from the proposed prohibition of importation of copies of the original authorized edition of the author's book.

The Vestal Bill, proposing the retention of the manufacturing provisions, also proposes elaborate provisions with respect to the prohibition of importation of authorized copies. The detailed consideration of these proposals for manufacture in the United States and the corresponding prohibition of importation does not come within the scope of this article, but the sections dealing with them are printed at the end of this article.

\section{SUMMARY}

The International Copyright Union consists of an association of States, parties to an agreement, pledging each of them re. ciprocally to protect the rights of authors, composers, artists and dramatists in their literary, musical, artistic and dramatic works. It now comprises the principal civilized countries of the world, excepting only the United States, China and Russia.

There are many reasons why the United States should be a member of this Union. Our entry into the Union is demanded as an act of fairness upon our part toward other countries which are members. While the United States is not a member and so not pledged to accord to foreign authors the reciprocal protection implied, our authors may automatically secure protec, tion for their works in all the countries of the Union by first or. simultaneous publication of such works in a Union country, for example, England. In other words, we secure the great advantages of the Union through a back door. This is not to our credit. As a noted copyright authority justly says: "It is not compatible with the dignity of a State to allow the international protection of its authors to depend on the unrequited generosity of foreign states."

The intellectual and professional classes of Europe have been left in a distressful situation in many countries by reason of the World War. They would be helped upon our entry into the Union by the improved American demand for their works which would result from the certainty of copyright protection here, and a new, secured market for their intellectual productions. On the other hand, the United States would undoubtedly greatly benefit by entry into the Copyright Union. The general public would be benefited by the increased diffusion of the best products of the intellectual and artistic productivity of Europe. Up to the present time it is estimated that out of the total annual European production of printed literary works, numbering hundreds of thousands, only a small percentage of such 
works are protected by copyright in the United States. The benefit to American authors, artists and composers would assuredly be considerable. It may be noted that American methods and ideas have had a greatly increased influence upon Europe since the war. Our wealth, our political and financial stability, and our relatively neutral situation, together with our extensive war philanthropies, have combined to emphasize the predominance of America throughout the world. All this necessarily means increased interest everywhere abroad in American books, music, plays, motion pictures and other intellectual productions. This is especially noticeable in England. The same thing is true, though in a lesser degree, of other European countries. A striking example is afforded by statistics of the spread of the American motion picture abroad. It is reported that in 1921 one hundred and forty million lineal feet of American film were exported, and that ninety per cent. of the pictures made in America are also used abroad. The increasing vogue of modern American music in Europe and South America is reflected in the great sales of American phonograph records.

These are the practical considerations to be taken into account. On the other hand, as a well-known English bookseller and publisher, who recently visited America, has said: "In the world of English written letters there is no principle of nationality in the sense in which it enters into commerce, politics and war. There is only at present a great free interchange of thought, of which everyone who reads reaps the benefit." That is the true basis of international copyright-the just and adequate protection of those who give such thought to the world for its benefit.

But America, in order to secure her full share of such benefit, must insist upon taking her proper place with the other intellectual producers of the world. To put herself on such a parity she should enter the Copyright Union now. She is peculiarly enjoined to take this step by present-day world conditions. She has held back for forty years; but she cannot afford to hold back much longer.

Provisions of the Vestal Bill (H. R. 10434) as to manufacture and importation:

SEC. 28. Of the printed books and periodicals specified in section 87 , subsections (a) and (b) of this Act, the text of all copies shall be printed stipulate that copies of such reprint shall not be brought into the United States: Provided, That such agreement shall have been recorded in the copyright office at Washington, and that the owner of the United States copyright shall have notified in writing the Secretary of the Treasury and the Postmaster General that the importation of copies of such Forl: is in contravention of such agreement: And provided furthcr, That, except as regards piratical copies, such prohibition of importation shall not 